\title{
An Investigation Into The Demand For Broad Money In South Africa
}

\author{
Moreblessing Simawu, University of Fort Hare, South Africa \\ Courage Mlambo, University of Fort Hare, South Africa \\ Genius Murwirapachena, Nelson Mandela Metropolitan University, South Africa
}

\begin{abstract}
A stable money demand function plays a vital role in the planning and implementation of monetary policy. With the use of Johansen co-integration and error correction model estimates, this study examines the existence of a stable long-run relationship between real broad money demand ( RM3) and its explanatory variables in South Africa for the period 1990-2009. In contrast to previous analyses, this study augments the co-integration and vector autoregression (VAR) analysis with impulse response and variance decomposition analyses to provide robust long-run effects and short-run dynamic effects on the real money demand. In addition, this study introduces a foreign interest rate to capture the impact of capital mobility on money demand in South Africa. Results from the Johansen test suggest that real broad money demand (RM3) and its all explanatory variables are cointegrated.
\end{abstract}

Keywords: Co-integration; Stability; Impulse Response; Coefficient

\section{INTRODUCTION}

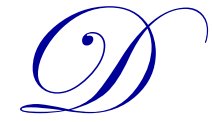

emand for money plays a major role in macroeconomic analysis, especially in selecting appropriate monetary policy actions (Ziramba, 2007:412). If the money demand function (the relationship between money demand and its determinants) is stable over the long run, money supply changes are closely related to prices and income, and it is possible for policy authorities to control inflation appropriately through the adjustments made to money supply (Hamori, 2008:1) and vice versa. The main purpose of this paper is to assess the impacts of the various determinants of real money demand on the South African money demand and to assess the stability of its function. The introduction of the foreign interest rate, as a separate determinant in the money demand function, is a significant departure from previous studies. In addition, this study augments the cointegration and vector autoregression (VAR) analysis with impulse response and variance decomposition analyses to provide robust long-run effects and short-run dynamic effects on the real money demand. Two different definitions of money demand will be considered: 1) M2, which consists of coins and notes in circulation, cheque and transmission deposits, other demand deposits, and other short-term and medium-term deposits, and 2) M3, which adds long-term deposits.

There have been a number of studies on the demand for money in South Africa, which include Maxwell (1971), Courakis (1984), Tavlas (1989), Hurn (1991), Hurn and Muscatelli (1992), Naude (1992), Nell (1999), Moll (1999), Jonsson (2001), Wesso (2002), Tlelima and Turner (2004), and Ziramba (2007).This study adds to the empirical work on money demand by extending the literature to recent years - a period characterised by a flexible exchange rate regime, an inflation targeting monetary policy framework, rising commodity prices, and meltdown of the global economy. There is a gap that further study on this topic may use a foreign interest rate to represent impact of capital mobility between countries in assessing the relationship between money demand and its determinants. Furthermore, there is need for a study that captures all changes in South Africa's economy, which include Freedom attainment in 1994, Asian financial crisis in 1998, adoption of formal inflation targeting in 2000, financial liberalisation, financial sector development, shifts in exchange rate policy, and the recent meltdown of the global economy.Consequently, examining the characteristics of the money demand function of South Africa, which has undergone significant changes since the 1980s, should bear significant meaning for present and future considerations of the SARB's monetary policy. 
The remainder of this paper provides a brief review of the empirical literature on money demand in South Africa, a review of international literature on money demand, an outline of the theoretical models, and a discussion of the Johansen co-integration and error correction model approach that is employed in this study. Data definitions and sources are cited in the methodology section, followed by a presentation of the empirical results and a conclusion.

\section{LITERATURE REVIEW}

\section{Empirical Literature From South Africa}

The demand for money has received a lot of attention in South Africa (see Maxwell, 1971; Courakis, 1984; Tavlas, 1989; Hurn, 1991; Hurn and Muscatelli, 1992; Naude, 1992; Moll, 1999; Nell, 1999; Moll, 2000; Jonsson, 2001; Wesso, 2002; Tlelima and Turner, 2004; Ziramba, 2007; and Todani, 2007). Courakis (1984), using quarterly data for the period 1965-1980, found that (i) opportunity costs in terms of financial assets are a significant determinant of the demand for narrow money and (ii) besides real income, the price level and opportunity costs, other factors appear to play a role in the demand for narrow money.

Tavlas (1989), using a buffer stock formulation for M3 demand, claims to identify a stable demand for M3. Hurn and Muscatelli (1992) use the Johansen method to estimate a co-integrating vector which links broad money to prices and interest rates. They found the following co-integrating relationship:

$(\text { Nominal M3 })_{t}=1.92 \times(\text { real GDP })_{t}+0.85 \times(\text { GDP deflator })_{t}+0.032(\text { deposit rate })_{t}-0.038 \times$ (interest rate on 3year government stock) $)_{\text {. }}$.

They used the own interest rate and interest rate on alternative assets as the opportunity cost variables. Moll (1999) explored relationships among money aggregates, interest rates, income and prices for the period 1965-1997, splitting the sample into periods before and after the liberalisation of the early 1980s. The money demand relationships examined did not co-integrate. It was suggested that the result could have been due to the omission of the inflation variable, the periodisation adopted, and the selection of co-integration tests. Jonsson (2001) determined that:

- A stable money demand type of relationship exists among domestic prices, broad money, real income, and nominal interest rates, with plausible estimates of the long-run coefficients, as well as a long-run relationship among domestic prices, foreign prices, and the nominal exchange rate.

- In the short run, shocks to the exchange rate affect domestic prices but have virtually no impact on real output, while shocks to broad money have temporary impact on real output before inflation picks up.

Wesso (2002) used the fixed-coefficient error-correction representation and the varying parameter regression approach to assess the impact of financial liberalisation on broad money demand in South Africa over the period 1971:1 to 2004:4. Tlelima and Turner (2004) found that the recursive estimates of the steady-state elasticities with respect to income, the interest rate, and the inflation rate indicate that these important parameters are not stable through the period. They found evidence that the income elasticity of money demand has increased significantly through the period as has the sensitivity of money demand to the opportunity cost of holding money balances. Naude (1992), using quarterly data for South Africa for the period 1972:1 to 1989:4, estimated a restricted error-correction model for money demand (M0). The findings of the study accepted the hypotheses of unit long-run elasticities of income and prices. The short-run income and price elasticities were higher than those found by other studies. It was concluded that error-correction models do have a contribution towards the understanding of money demand in South Africa.

None of the existing studies investigated the impacts of capital mobility on money demand and none of the studies explored the dynamics between money demand and its determinants as shown by variance decomposition analyses and impulse response analysis on the South African demand for money. Therefore, this study focuses on assessment of the stability of money demand function when capital mobility is taken into consideration and the dynamics of relationships between money demand and its determinants in South Africa. 


\section{INTERNATIONAL LITERATURE REVIEW}

Bahmani-Oskooee and Gelan (2008) studied the stability of M2 money demand in 21 African countries $^{1}$ in perhaps the only comprehensive study in the literature pertaining to Africa. The method of estimation is the bounds testing approach to co-integration and error-correction modeling. They used quarterly data over the period 1971Q1 to 2004Q3 and found that the demand for M2, the inflation rate, income, and the nominal effective exchange rate in all countries are co-integrated. Application of the CUSUM (Cummulative Sum) and CUSUMSQ (Cumulative Sum of Squares) tests revealed that the estimated models are stable in almost all countries.

Hamori (2008) empirically analyzed the money demand function in the Sub-Saharan African region using a non-stationary panel data analysis. The study conducted the analysis on 35 countries $^{2}$ based on annual data from 1980 to 2005. The empirical results revealed that there exists a co-integration relation with respect to money demand in the Sub-Saharan African region over the period from 1980 and 2006, regardless of whether M1 or M2 is used as the money supply measure. Bahmani-Oskooee and Shin (2002) investigated the demand for money in Korea using quarterly data covering the period 1975Q1 to 1995Q4. In contrast to a few previous studies that applied cointegration technique in estimating the money demand function in Korea, which interpreted co-integration among the variables of money demand as a sign of a stable money demand function, advances in the literature show that cointegration among a set of variables does not imply that the estimated co-integrating vector is necessarily stable. Bahmani-Oskooee and Shin (2002) employed the CUSUM and CUSUMSQ tests along with the Johansen's cointegration framework to test for the stability of the long-run coefficient estimates as well as the short-run dynamics of MI, M2 and M3 money demand function in Korea. The empirical results showed that in Korea none of the monetary aggregates have a stable relation with income, interest rate and exchange rate.

Bahmani-Oskoee (2001) investigated the stability of money demand in Japan using the ARDL approach combined with CUSUM and CUSUMSQ tests. Quarterly data over 1964Q1-1996Q3 were used. The results showed that in Japan, M2 monetary aggregate was cointegrated with income and interest rate during the period of study. In addition, application of CUSUM and CUSUMSQ test to an error correction model showed that the long-run money demand in Japan is stable. Bahmani-Oskooee and $\mathrm{Ng}$ (2002) examined the long-run demand for money in Hong Kong using quarterly data over the period 1985Q1-1999Q4. By applying the autoregressive distributed lag (ARDL) co-integration procedure, a long-run relationship between real broad money aggregate, real income, nominal interest rates, foreign interest rates, and foreign exchange rates was observed. Both the CUSUM and CUSUMSQ tests also confirmed the stability of long-run coefficients of the money demand function.

\section{METHODOLOGY}

\section{Model Specification}

In formulating the money demand for South Africa, the quantity theory of money is modified to accommodate empirical literature; hence, the following specification is adopted:

$$
M_{t}=f(Y, C P I, E X, I R, I f)
$$

where $\left(M_{t}\right)$ is a function of GDP (Y), Inflation rate $(C P I)$, interest rate (IR), foreign interest rate (If ) and real exchange rate (EX).

The model to be estimated will be written as follows:

$$
\ln R M_{t}=a+b \ln Y_{t}+c \ln C P I_{t}+d \ln E X_{t}+e \ln I R_{t}+f \ln I f_{t}+\varepsilon_{t}
$$

\footnotetext{
${ }^{1}$ The list of countries included in their analysis are Burkina Faso, Burundi, Cameroon, Co`te d'Ivoire, Egypt, Ethiopia, Gabon, Ghana, Kenya, Madagascar, Mauritius, Morocco, Niger, Nigeria, Rwanda, Senegal, the Seychelles, Sierra Leone, South Africa, Tanzania, and Togo.

${ }^{2}$ The countries include Benin, Botswana, Burkina Faso, Burundi, Cameroon, Cape Verde, Central African Republic, Chad, Congo, Rep., Cote d'Ivoire, Equatorial Guinea, Ethiopia, Gabon, Gambia, Ghana, Kenya, Lesotho, Liberia, Madagascar, Malawi, Mali, Mauritania, Mauritius, Niger, Nigeria, Rwanda, Senegal, Seychelles, Sierra Leone, South Africa, Swaziland, Togo, Uganda, Zambia, Zimbabwe.
} 
where $\boldsymbol{L n} \boldsymbol{R M}$ is natural logarithm of a monetary aggregate in real terms (broad definition M3). To obtain the real money balances, M3 was divided by the GDP deflator.

$\boldsymbol{L n} \boldsymbol{E X}$ is the natural logarithm of the real effective exchange rate of the rand, measured in foreign currency terms. Thus, an increase in this variable indicates an appreciation of the rand and a decrease indicates a depreciation of the rand.

$\operatorname{Ln} \boldsymbol{Y}$ is the natural logarithm of real income, which is a measure of economic activity. Seasonally-adjusted real GDP was used for national income in order to remove the influence of seasonal fluctuations on the model.

$\boldsymbol{L n} I \boldsymbol{R}$ is the natural logarithm of the prime overdraft rate at which banks are willing to lend money to the general public. This rate of interest is very crucial in determining the level of investment in the economy.

Ln CPI is the natural logarithm of CPI (a measure of the rate of inflation) which measures price change for a constant market basket of goods and services from one period to another in South Africa's metropolitan and urban areas. The choice of CPI is justified in that this rate is officially targeted by SARB and monetary policy is formulated to keep CPI in the target range (3-6\%).

Ln If is the natural logarithm of foreign interest rate (US bank prime loan rate). The US is selected on the basis that it is one of South Africa's major trading partners over the period of this study.

Also, $b, c, d$ and $e$ are the coefficients to be estimated and $\varepsilon_{t}$ is the error term. The error term represents the influence of the omitted variables in the construction of the data.

\section{Data Sources and Expected Signs of Coefficients}

In this study the data on GDP, inflation, Monetary aggregates, and exchange rate will be obtained from the Department of Trade and industry's website and the SARB reports. The data for the foreign interest rate is obtained from the Federal Reserve's website. The data covers the period 1990Q1 - 2009Q4.

Following the transaction demand for money or quantity theory, it is expected that an estimate of income elasticity, $b$, will be positive. An estimate of inflation elasticity is expected to be negative, for inflation measures the opportunity cost of holding money. In most developing countries, at a high rate of inflation people hold less money and more real assets since prices are rising (Bahmani-Oskooee and Gelan, 2008:218). As Equation (1) shows, $E X$ is the effective exchange rate. By way of construction, a decrease reflects a depreciation of domestic currency or an appreciation of the foreign currency (Bahmani-Oskooee and Gelan, 2008:218). A depreciation of the domestic currency raises the domestic currency value of foreign assets held by domestic residents. If this increase in the value of foreign assets is perceived as an increase in wealth, the demand for domestic currency should increase, yielding a negative estimate for $d$ (Arango and Nadiri, 1981, in Bahmani-Oskooee and Gelan, 2008:218). On the other hand, as domestic currency depreciates, if domestic residents expect further depreciation, they would indeed hold less domestic currency (Bahmani-Oskooee and Pourheydarian, 1990, in Bahmani-Oskooee and Gelan, 2008:218). Hence, an estimate of $d$ can also be positive. A higher foreign interest rate may reduce money demand because of the capital mobility effect or increase money demand because of the cost of borrowing effect (Marquez, 1987; BahmaniOskooee and $\mathrm{Ng}, 2002$ ). Since the signs for the real exchange rate and the foreign interest rate in the money demand function are unclear, empirical estimation is needed to determine the relationship between the two variables (foreign interest rate and exchange rate) and real money demand.

\section{Test For Stationarity}

The test for stationarity of the individual series in the economic model was undertaken using the augmented Dickey-Fuller (ADF) and Phillips-Perron unit root tests procedure in E-Views version 7. The number of lagged term $\mathrm{p}$ was set to be chosen automatically by E-Views software to ensure the errors are uncorrelated. The test series is said to be non-stationary if the ADF test revealed the Null Hypothesis that $\alpha_{1}=0$ could not be rejected against an alternative that $\alpha_{1}<0$, and stationary if otherwise. Economic series are said to be integrated of order d, denoted as 
$I(d)$, where the order of integration is the number of unit roots contained in the series or the number of differencing operations it takes to make the series stationary. Following evidence in this study, which revealed that the series in the economic model is generally I(1) series (see Tables 1 and 2 for results of unit root tests), it became obvious that least square technique would not be appropriate for the estimation of the economic model. Thus, bearing in mind the need to accommodate the interdependence of relationships between most economic variables, the economic model was re-conceptualized as a vector auto-regressive system (4), allowing for the possibility of co-integration among the endogenous variables.

$$
\Delta Y_{t}=\prod Y_{t-1}+\sum_{i=1}^{p-1} \Gamma_{i} \Delta Y_{t-i}+B x_{t}+\varepsilon_{t}
$$

where $\mathrm{x}$ is vector of deterministic variables, constant (C) and/or trend; $\mathrm{Y}$ is vector of $\mathrm{I}(1)$ endogenous variables, including real broad money (RM3), $\ln Y, \ln C P I, \operatorname{lnEX}, \operatorname{lnIR}$ and $\ln$ If; $\Pi B$, Гand $\Pi$ are matrices of coefficients to be estimated, while $\varepsilon$ is vector of stochastic residuals.

Terms in B give the influence of the associated deterministic variables, while $\Gamma$ represents short-term elasticities of response. By Granger's representation theorem, if the coefficient matrix $\Pi$ in Equation (3) has reduced rank $\mathrm{r}<\mathrm{k}(\mathrm{k}=4$, in this case), which implies that $\mathrm{r}$ distinct linearly dependent associations of endogenous variables in $\mathrm{Y}_{\mathrm{t}}$ exists, then there exist $\mathrm{k} \times \mathrm{r}$ matrices $\alpha$ and $\beta$ each with rank $r$, such that $\Pi=\alpha \beta^{\prime}$ and $\beta^{\prime} Y_{t}$ is stationary (E-Views, 2007:686). In this case, $r$ is the number of co-integrating relations (the rank), while each column of $\beta$ is the cointegrating vector. The elements of $\alpha$ are the adjustment parameters in the vector error correction model.

\section{Co-integration Test}

The next stage in the examination of statistical properties of the series was a test for co-integration among the endogenous variables in the VAR system in Equation (1). This was implemented in E-Views using procedures from Johansen $(1992,1995)$ system based techniques. In testing for the number of co-integrating vectors among economic time series, Johansen's $(1992,1995)$ system approach is to estimate the $\Pi$ matrix in an unrestricted form and then test whether the restrictions implied by the reduced rank of $\Pi$ (E-Views, 2007) can be rejected. The software provides procedures for conducting both a maximum Eigen value and trace statistic-based co-integration tests, which were employed in this study.

It is essential to consider two important issues before proceeding to test for the rank of $\Pi$. Initially, the appropriate order $(k)$ of the VAR should be determined. The Johansen method is affected by the lag length employed and, hence, it is critical to decide on the optimal lag length (Brooks, 2002:404). Brooks proposes the use of multivariate versions of information criteria, which includes the sequential modified likelihood ratio (LR), Akaike information criterion (AIC), Hannan-Quinn information criterion (HQ) and the Final prediction error (FPE) Schwarz information criterion (SIC). However, the preceeding information criteria frequently produce contradictory VAR lag order selections; therefore, it is vital to use both information criterion approach and a priori knowledge from economic theory to select proper order of the VAR.

The second issue relates to the selection from the various types of VARs based on five deterministic assumptions. Eviews 7 provides the following deterministic trend assumptions:

- Case 1 assumes no deterministic trend in the data and no intercept or trend in the VAR and in the cointergrating equation (CE).

- $\quad$ Case 2 assumes no deterministic trend in the data, but an intercept in the CE and no intercept in the VAR.

- $\quad$ Case 3 assumes a linear deterministic trend in the data and an intercept in the CE trend in VAR.

- $\quad$ Case 4 allows for a linear deterministic trend in data, intercept and trend in CE and no trend in VAR.

- $\quad$ Case 5 allows for a quadratic deterministic trend in data, intercept and trend in CE and linear trend in VAR.

As a guide, Eviews 7 advises the use of Case 2 if none of the series has a trend, Case 3 if all trends are stochastic, and Case 4 if some of the series are trend stationary. Case 1 is used when all series have zero mean and 
Case 5 may provide a good fit in-sample but will produce implausible forecasts out-of-sample, which makes both rarely used. Case 6 contains a summary of all five trend assumptions and assists in determining the choice of the trend assumption (Eviews 7 User Guide 2: 687)

\section{The Final VEC Model, Impulse Response Functions And Variance Decomposition}

On the basis of evidence from various diagnostic and specification tests, the final specification of the statistical model in Equation (3) was finally estimated as a Vector Error Correction (VEC) model, with one CE imposed, up to four lags allowed for each of the endogenous variables in the VAR, and with constant (no trend) allowed in the CE. This final specification served as the basis for assessing the influence of the rate of inflation, the exchange rate and foreign interest rates, as well as national income on both the short- and long-run variation of real broad money (represented by M3) in South Africa. The relative importance of the variables in impacting real money demand fluctuations in South Africa was also assessed by impulse response and variance decomposition analyses. The stability of broad money demand in South Africa was then tested using CUSUM and CUSUMSQ tests.

\section{RESULTS AND DISCUSSION}

\section{Results Of Unit Root Tests}

As a pre-condition for estimation of the model describing the relationship between real money demand and its determinants in South Africa, the Augmented Dickey Fuller (ADF) and Phillips-Perron tests were employed to verify stationarity (or presence of Unit roots) in the individual series of the model. The results are summarised in Tables 1 and 2. As shown in the tables, the series in the economic model is generally I(1) series, given that they are all nonstationary in their levels, but stationary in their first difference for ADF tests at $1 \%$ and $5 \%$ level of significance. It thus implies that their inclusion in classical least square regressions is most likely going to produce spurious results (Granger and Newbold, 1974). Thus, the economic model that describes the relationship between real money demand and its determinants in South Africa was re-specified as a VAR, as earlier defined in Equation (2).

Table 1: Augmented Dickey Fuller Stationarity Test

\begin{tabular}{|l|c|c|c|c|c|c|}
\hline \multicolumn{2}{|c|}{ Augmented Dickey- Fuller Unit root test } & \multicolumn{2}{c|}{ First Difference } \\
\hline \multicolumn{1}{|c|}{ Variables } & Constant & $\begin{array}{c}\text { Constant } \\
\text { and Trend }\end{array}$ & None & Constant & $\begin{array}{c}\text { Constant } \\
\text { and Trend }\end{array}$ & None \\
\hline LEX & -2.01 & -2.27 & -0.28 & $-8.37^{*}$ & $-8.32^{*}$ & $-8.42^{*}$ \\
\hline LGDP & 0.46 & -3.03 & 2.60 & $-3.80^{*}$ & $-3.95^{*}$ & $-2.68^{*}$ \\
\hline LIR & -1.80 & -3.00 & -0.93 & $-5.66^{*}$ & $-5.63^{*}$ & $-5.62^{*}$ \\
\hline LM3 & 0.53 & -2.10 & -1.23 & $-5.47^{*}$ & $-5.48^{*}$ & -1.23 \\
\hline LM2 & -0.15 & -2.56 & 13.24 & $-6.77^{*}$ & $-6.72^{*}$ & $-1.73^{* * *}$ \\
\hline CPI & $-3.89 *$ & $-4.37^{*}$ & -0.88 & $-6.87^{*}$ & $-6.89^{*}$ & $-6.91^{*}$ \\
\hline LIf & -2.15 & $-4.33^{*}$ & -1.07 & $-4.07^{*}$ & $-4.06^{*}$ & $-4.01^{*}$ \\
\hline CV (5\%) & -2.90 & -3.47 & -1.94 & -2.90 & -3.47 & -1.94 \\
CV (1\%) & -3.52 & -4.08 & -2.59 & -3.52 & -4.08 & -2.59 \\
\hline
\end{tabular}

\section{Notes}

(1) The null hypothesis, $\mathrm{H}_{0}=$ Variables have a unit root.

(2) $*, * *$ and $* * *$ represent a stationary variable at $1 \%, 5 \%$ and $10 \%$ level, respectively.

(3) The critical values are obtained from MacKinnon (1996) one-sided p-value.

(4) The appropriate lag lengths are selected by Akaike information Criteria and Eviews programme automatically selected the appropriate lag length.

(5) CV stands for Critical Values. 
Table 2: Phillips-Perron Stationarity Test

\begin{tabular}{|l|c|c|c|c|cc|}
\hline \multicolumn{2}{|c|}{ Phillips-Perron (PP) Unit Root Test } \\
\hline \multicolumn{1}{|c|}{ Variables } & Constant & $\begin{array}{c}\text { Constant } \\
\text { and Trend }\end{array}$ & None & Constant & \multicolumn{2}{c|}{$\begin{array}{c}\text { Constant Difference } \\
\text { and Trend }\end{array}$} \\
\hline LEX & -2.04 & -2.36 & -0.28 & $-8.37^{*}$ & $-8.32^{*}$ & $-8.42^{*}$ \\
\hline LGDP & 1.07 & -2.91 & 4.29 & $-3.65^{*}$ & $-3.89^{* *}$ & $-2.53^{* *}$ \\
\hline LIR & -1.43 & -2.45 & -1.04 & $-5.67^{*}$ & $-5.65^{*}$ & $-5.64^{*}$ \\
\hline LM3 & -.84 & -2.08 & 11.28 & $-5.51^{*}$ & $-5.53^{*}$ & $-1.90^{* * *}$ \\
\hline LM2 & -0.17 & -2.40 & 11.84 & $-6.77^{*}$ & $-6.72^{*}$ & $-2.87^{*}$ \\
\hline CPI & -2.85 & -2.88 & -1.18 & $-4.78^{*}$ & $-4.73^{*}$ & $-4.83^{*}$ \\
\hline LIf & -1.58 & -2.11 & -1.14 & $-4.17^{*}$ & $-4.16^{*}$ & $-4.10^{*}$ \\
\hline CV $(\mathbf{5 \% )}$ & -2.90 & -3.47 & -1.94 & -2.90 & -3.47 & -1.94 \\
CV $(\mathbf{1 \% )}$ & -3.52 & -4.08 & -2.59 & -3.52 & -4.08 & -2.59 \\
\hline
\end{tabular}

\section{Notes}

(1) The null hypothesis, $\mathrm{H}_{0}=$ Variables have a unit root.

(2) $* * *$ and $* * *$ represent a stationary variable at $1 \%, 5 \%$ and $10 \%$ level of significance, respectively.

(3) The critical values are obtained from MacKinnon (1996) one-sided p-value.

(4) The lag length is decided according to Newley-West's (1987).

(5) CV means Critical Value.

\section{Optimal Lag Length in The VAR}

A major requirement in conducting Johansen $(1992,1995)$ co-integration tests and estimation of a VAR system - either in its unrestricted or restricted Vector Error Correction (VEC) forms - is the choice of an optimal lag length. In this study, this choice was made by examining the lag structure in an unrestricted VAR originally specified with four lags, using a combination of VAR lag order selection criteria and examination of the roots of the characteristic polynomial to verify if the VAR is stable. Table 3 presents the evidence based on the VAR Lag Order Selection Criteria, while Figure 1 presents the inverse roots of the AR characteristic polynomial associated with the different lag orders specified by the selection criteria. As shown in Table 3, the LR, HQ FPE and AIC criteria suggest the use of four lags, while the SC criterion suggests that the use of one lag should be accommodated in the VAR. This shows that the VAR in Equation (3) will be unstable if only one is accommodated. Thus, subsequent analyses were based on VAR with four lags.

Table 3: Lag Selection Criteria

\begin{tabular}{|c|c|c|c|c|c|c|}
\hline \multicolumn{7}{|c|}{ VAR Lag Order Selection Criteria } \\
\hline \multicolumn{7}{|c|}{ Endogenous variables: LRM3 Y LCPI LEX LIR LIF } \\
\hline \multicolumn{7}{|c|}{ Exogenous variables: $\mathrm{C}$} \\
\hline \multicolumn{7}{|c|}{ Date: $08 / 22 / 11$ Time: $14: 45$} \\
\hline \multicolumn{7}{|c|}{ Sample: 1990Q1 2009Q4 } \\
\hline \multicolumn{7}{|c|}{ Included observations: 76} \\
\hline Lag & $\log L$ & LR & FPE & AIC & SC & HQ \\
\hline 0 & 174.4971 & NA & $4.78 \mathrm{e}-10$ & -4.434133 & -4.250128 & -4.360596 \\
\hline 1 & 707.2381 & 967.3456 & $1.01 \mathrm{e}-15$ & -17.50627 & $-16.21823^{*}$ & -16.99150 \\
\hline 2 & 767.4268 & 99.78640 & $5.43 \mathrm{e}-16$ & -18.14281 & -15.75074 & -17.18682 \\
\hline 3 & 816.3637 & 73.40545 & $4.04 \mathrm{e}-16$ & -18.48326 & -14.98716 & -17.08605 \\
\hline 4 & 876.3280 & $80.47843^{*}$ & $2.35 \mathrm{e}-16^{*}$ & $-19.11390 *$ & -14.51376 & $-17.27546^{*}$ \\
\hline \multicolumn{7}{|c|}{$*$ indicates lag order selected by the criterion } \\
\hline \multicolumn{7}{|c|}{ LR: sequential modified LR test statistic (each test at 5\% level) } \\
\hline \multicolumn{7}{|c|}{ FPE: Final prediction error } \\
\hline \multicolumn{7}{|c|}{ AIC: Akaike information criterion } \\
\hline \multicolumn{7}{|c|}{ SC: Schwarz information criterion } \\
\hline HQ: Hann & information & & & & & \\
\hline
\end{tabular}




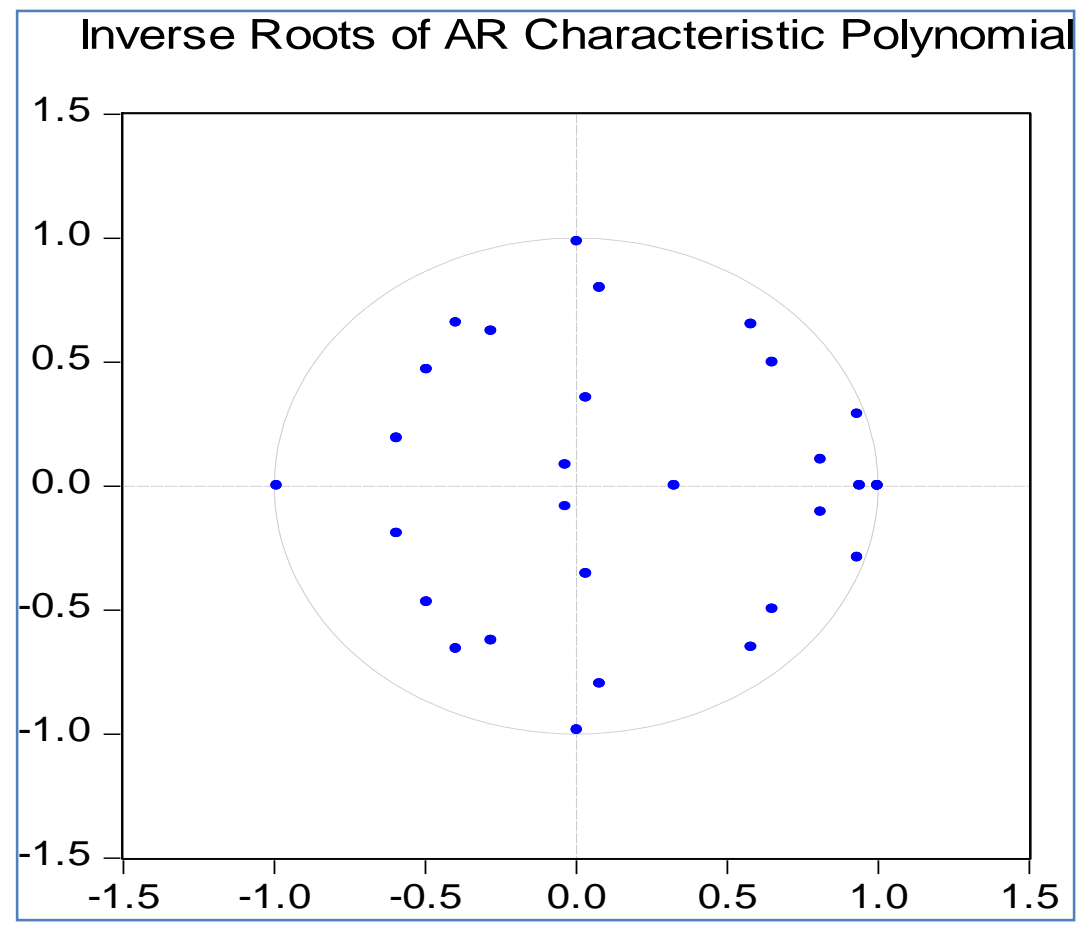

Figure 1: Inverse Roots of AR Characteristic Polynomial

\section{Deterministic Specification And Co-integration Test}

Having selected the optimal lag length for the VAR system, the choice of how deterministic terms, constant and trend, should be accommodated in the candidate Vector Error Correction (VEC) model, which had to be made before the Johansen $(1992,1995)$ system-based co-integration test could be performed, was made by application of the Pantula principle (Johansen, 1992). This entailed selection of the least restrictive specification among those specifications having the lowest number of co-integrating equations (CE), if more than one. All five possible specifications were tested. The Johansen co-integration test is therefore conducted using the assumption of no trend but a constant in the series and 4 lags for the VAR. Tables 4 presents the co-integration test results for the specified money demand models applying the trace and maximum eigenvalue test statistics. The upper part of Table 4 presents the Johansen co-integration test based on the trace test, while the bottom part presents the results of this test based on the maximum eigenvalue test.

In Table 4, the null hypothesis that there are, at most, three co-integrating vectors cannot be rejected since the test statistic of approximately 28.62 is now less than the $5 \%$ critical value of approximately 29.80 . The maximum eigenvalue test also rejects the null hypothesis of no co-integration; it suggests that there is only one cointegrating relationship in the M3 demand model.The trace test and the maximum eigenvalues test evidently generate conflicting results in Table 4. However, in such a situation, Johansen and Juselius (1990) advise the examination of the estimated co-integrating vector and base the choice on the interpretability of the co-integrating relations.

The main implication of the foregoing is that even though the real broad money demand in South Africa and its hypothesised determinants are generally I(1) series, some stable long-run equilibrium relationship exists among the series, which could be given some error correction representations (Engle and Granger, 1987). It also shows that the finding of no causality in the relationship between them (in the Granger ${ }^{3}, 1969$ sense) is ruled out (Granger, 1986 and 1989), just as the possibility of the estimated relationship being spurious is also ruled out (Masih

${ }^{3}$ Granger approach to the question of whether $\mathrm{x}$ causes $\mathrm{y}$ is to see how much of the current $\mathrm{y}$ can be explained by past values of $\mathrm{y}$ and then to see whether adding lagged values of $\mathrm{x}$ can improve the explanation. Thus $\mathrm{y}$ is said to be Granger-caused by $\mathrm{x}$ if $\mathrm{x}$ helps in the prediction of $\mathrm{y}$, or equivalently, if the coefficients of the lagged x's are statistically significant (Eviews, 2007). 
and Masih, 1998, in Onanuga, and Shittu, 2010). The estimated long-run relationship (t-ratio in parentheses), based on normalisation in respect of TBR and domestic output, may be written as:

$$
L R M 3=46.27+\underset{[21.0439]}{2.16 Y}-\underset{[-2.8655]}{0.09 C P I}+\underset{[-2.0830]}{0.25 L E X}-\underset{[-2.13112]}{0.20 L I R}+\underset{[5.0965]}{0.34 L I F}
$$

Empirical results show that income elasticity has a positive relationship with real broad money demand. This is consistent with the transaction demand for money or quantity theory. In Equation (4), a $1 \%$ change in real income (Y) will cause a $2.2 \%$ change in real M3. The results are consistent with other empirical work on money demand which showed a positive relationship between real money balances and income. This includes BahmaniOskooee and Gelan (2008), Hsing, Y(2007), Bahmani-Oskooee and Ng (2002). The income elasticity obtained in this model is higher than unity, contrary to what the quantity theory would suggest, and, in general, is relatively higher than those obtained from other related studies. However, estimates that are higher than unity are not uncommon in empirical money demand studies. ${ }^{4}$ An estimate of inflation elasticity has a negative coefficient as expected, for inflation measures the opportunity cost of holding money. In most developing countries, at a high rate of inflation people hold less money and more real assets since prices are rising (Bahmani-Oskooee and Gelan, 2008:218). The positive coefficient obtained for the foreign exchange rate (LEX) lends support to the currency substitution argument. Exchange rate depreciation induces currency substitution in favour of foreign currency and reduces the demand for domestic money. The prime overdraft rate (LIR) has the expected negative interest rate elasticity. A $1 \%$ rise in interest rate will result in a $-0.2 \%$ change in demand for real $\mathrm{M} 3$ balances. The foreign interest rate has a positive coefficient. Since the signs for the nominal exchange rate and the foreign interest rate in the money demand function are unclear in theory, empirical estimation is needed to determine whether a change in the exchange rate or the foreign interest rate would positively or negatively affect the demand for money. The positive coefficient obtained for the foreign interest rate, however, seems to support the less conventional argument as provided by Marquez (1987) rather than the capital mobility effect.

Table 4: Vector Error Correction Model For Real M3 Demand

\begin{tabular}{|l|c|c|c|c|c|c|}
\hline Error Correction: & D(LRM3) & D(Y) & D(LCPI) & D(LEX) & D(LIR) & D(LIF) \\
\hline CointEq1 & -0.161854 & -0.024272 & -0.294368 & 0.340990 & -0.219788 & 0.371459 \\
\hline & $(0.05156)$ & $(0.01383)$ & $(0.64249)$ & $(0.11310)$ & $(0.14727)$ & $(0.13049)$ \\
\hline & {$[-3.13926]$} & {$[-1.75562]$} & {$[-0.45817]$} & {$[3.01490]$} & {$[-1.49241]$} & {$[2.84665]$} \\
\hline & & & & & & \\
\hline CointEq2 & 0.357655 & 0.046726 & 0.871215 & -0.719167 & 0.320823 & -0.780986 \\
\hline & $(0.11221)$ & $(0.03009)$ & $(1.39836)$ & $(0.24616)$ & $(0.32053)$ & $(0.28401)$ \\
\hline & {$[3.18725]$} & {$[1.55284]$} & {$[0.62302]$} & {$[-2.92151]$} & {$[1.00091]$} & {$[-2.74988]$} \\
\hline CointEq3 & & & & & & \\
\hline & -0.018046 & -0.001318 & -0.077942 & 0.022527 & 0.022656 & 0.030522 \\
\hline & $(0.00686)$ & $(0.00184)$ & $(0.08555)$ & $(0.01506)$ & $(0.01961)$ & $(0.01737)$ \\
\hline & {$[-2.62885]$} & {$[-0.71602]$} & {$[-0.91111]$} & {$[1.49592]$} & {$[1.15541]$} & {$[1.75670]$} \\
\hline
\end{tabular}

A higher foreign interest rate may reduce money demand because of the capital mobility effect or it may increase money demand because of the cost of borrowing effect (Marquez, 1987; Bahmani-Oskooee and Ng, 2002). The outcome of the estimated VECM, without any restrictions is presented in Table 4 for the three co-integrating relations identified by the trace test and maximum eigenvalue test for the Real M3 demand model.

In Table 4, the speed of adjustment is indicated by the coefficients of the error correction terms. In the first co-integration relationship, M3, Y, CPI and IR have coefficients that are negative, indicating that these variables converge to their long-run equilibrium. However, EX and IF have positive coefficients, indicating that any disequilibrium in EX and IF continues to grow. Their t-values are -3.13926, -1.75562, -0.45817 and -1.49241 , respectively.All the variables, with the exception of M3 and Y, are not significant. In the second co-integration equation, only EX and LIF show evidence of error correction, meaning they converge to their long-run equilibrium if disturbed. In the third co-integration equation, only LM3 shows evidence of error correction.

\footnotetext{
${ }^{4}$ Wesso (2002) found an income elasticity of about 1.8 for South Africa, Todani (2007) found an income elasticity of $3.2 \%$ for South Africa and Al Samara (2010) found an income elasticity of 1.73 for money demand in Syria.
} 


\section{Diagnostic Checks}

The VAR model was subjected to rigorous diagnostic tests. Diagnostic checks are crucial in this analysis because if there is a problem in the residuals from the estimation of the model, it will be an indication that the model is not efficient, such that parameter estimates from such a model may be biased. The VAR was tested for AR Roots test and serial correlation and the results are indicated in Figure 1. The AR Roots Graph reports the inverse roots of the characteristic AR polynomial. The estimated VAR is stable (stationary) if all roots have modulus less than one and lie inside the unit circle. If the VAR is not stable, certain results, such as impulse response standard errors, are not valid. Figure 1 shows that all roots lie inside the unit circle, which is an indication that the VAR is stable.

The diagnostic test results are presented in Table 5, which assist in checking for serial correlation, normality and heteroskedasticity. These diagnostic checks are based on the null hypothesis that there is no serial correlation for the LM test, there is normality for the Jarque-Bera test, and that there is no heteroskedasticity for the White heteroskedasticity test. The estimated models fit satisfactorily well with an $\mathrm{R}^{2}$ of $66 \%$ for real M3 demand. The LM test, which is a stricter test for correlation, is also applied in the analysis and the results (p-value of 0.6631) show that there is no serial correlation at four lags used for the real M3 demand model (see Table 5). As for the normality test, the authors reject the null hypothesis of a normal distribution as the JB test statistic of 1890.241 with a $\mathrm{p}$ value of 0.0000 is a clear indication of non normality at 1 and 5 percent. The results for the diagnostic checks for serial correlation and heteroskedasticity show that the data are fairly well behaved. Results indicate the presence of non-normal residuals but, as indicated by Gonzalo (1994), Johansen method still provides the most robust results than the other methods, even when the errors are non-normal (Choudhry, 2008:612). In addition, Johansen and Juselius (1990 and 1992, in Islam and Ahmed, 1999: 105) also observed non normal residuals in their studies.

Table 5: Diagnostic Tests

\begin{tabular}{|l|c|c|c|c|}
\hline & $\begin{array}{c}\text { Normality Test: (Jarque Bera) } \\
\text { Orthogonalisation: Residual } \\
\text { Covariance(Urza) }\end{array}$ & $\begin{array}{c}\text { Heteroscedasticity: White's Test } \\
\text { (No Cross Terms) }\end{array}$ & $\begin{array}{c}\text { Serial Correlation: } \\
\text { LM Test }\end{array}$ & \multicolumn{1}{|c|}{$\mathbf{R}^{\mathbf{2}}$} \\
\hline M3 & $1890.241(0.0000)$ & $1095.911(0.77867)$ & $31.91859(0.6631)$ & 0.66 \\
\hline *p -values in brackets ( ).
\end{tabular}

\section{Impulse Response Analysis}

These impulse response functions show the dynamic response of the real M3 money demand to a oneperiod standard deviation shock to the innovations of the system and also indicate the directions and persistence of the response to each of the shocks over a 10-quarter (2.5years) period. For the most part, the impulse response functions have the expected pattern and confirm the results from the short-run relationship analysis. In Figure 2, shocks to two of the variables are not significantly different from zero and are transitory, while shocks to the other four variables are significant, but only two are persistent. A one-period standard deviation shock to EX and IR marginally appreciates the real M3 money demand, but the impact dies off quickly, on average. A shock to LCPI has a marginal depreciation effect on the real M3 money demand in the short run, but is also permanent. A one-period standard deviation shock to LIF appreciates the real M3 money demand less than 1 percent but also gradually rises in about two and one half years. Variables that have persistent and significant effects on the real M3 money demand are the real M3 money, national income, rate of inflation, and the foreign interest rate. The response of the real M3 money demand to a one-period shock to prime overdraft rate is a transitory appreciation. This result implies that expansionary monetary policy appreciates the real M3 demand in the short run.

Finally, a shock to the national income has a lasting positive impact on the real M3 money demand. A oneperiod shock to the national income appreciates the real M3 money demand by nearly two percent in one year's time and continues to grow. Thus, the real M3 money, national income, rate of inflation, and the foreign interest rate have a significant impact on the real M3 money demand in the short run. However, remaining variables (the real exchange rate and prime overdraft rate) have only a transitory effect on the real M3 money demand. Since this study focuses on the determinants and stability of real M3 money demand, only the responses of the real broad ( M3) money demand to shocks in its determinants are reported in Figure 2.

\section{Variance Decomposition Analysis}


Variance decomposition analysis provides a means of determining the relative importance of shocks in explaining variations in the variable of interest. In the context of this study, it therefore provides a way of determining the relative importance of shocks to each of the determinants of the real broad money demand (M3) in explaining variations in the real money demand. The results of the variance decomposition analysis are presented in Table 6, which show the proportion of the forecast error variance in the real money demand (M3) explained by its own innovations and those in its determinants.

Since this study focuses on the movements of the real money demand following shocks to itself or its determinants, only the variance decomposition in the real money demand (M3) is reported and the relative importance of each of its determinants in influencing money demand changes is analysed. While the information criteria suggested that lag order 4 for the VAR models was sufficient, the variance decompositions for 10 quarters ( 2.5 years) is allowed in order to determine the effects when the variables are allowed to affect the real money demand for a relatively longer time. In the first quarter, all of the variance in the real money demand (M3) is explained by its own innovations (shocks), as suggested in Brooks (2002: 342).

Table 6: Variance Decomposition

\begin{tabular}{|c|c|c|c|c|c|c|c|}
\hline \multicolumn{2}{|c|}{} & & $\begin{array}{c}\text { Variance } \\
\text { Decomposition of LRM3: }\end{array}$ & & & \\
\hline Period & S.E. & LRM3 & Y & LCPI & LEX & LIR & LIF \\
\hline 1 & 0.020143 & 100.0000 & 0.000000 & 0.000000 & 0.000000 & 0.000000 & 0.000000 \\
\hline 2 & 0.025155 & 87.51717 & 0.007607 & 0.396849 & 3.356237 & 5.271722 & 3.450418 \\
\hline 3 & 0.030939 & 82.38673 & 0.480657 & 2.362095 & 7.770874 & 3.555119 & 3.444522 \\
\hline 4 & 0.035210 & 74.31235 & 6.002694 & 2.256338 & 9.403451 & 3.197328 & 4.827834 \\
\hline 5 & 0.043344 & 71.42348 & 8.792381 & 2.542656 & 8.493132 & 2.139239 & 6.609115 \\
\hline 6 & 0.051462 & 64.71173 & 11.65839 & 2.823463 & 7.664127 & 2.087955 & 11.05433 \\
\hline 7 & 0.061424 & 61.23071 & 10.98484 & 4.056254 & 6.276673 & 1.499131 & 15.95239 \\
\hline 8 & 0.071011 & 56.99715 & 11.22469 & 5.483252 & 4.873358 & 1.162151 & 20.25940 \\
\hline 9 & 0.082554 & 54.95504 & 10.48469 & 6.989283 & 3.615708 & 1.232869 & 22.72242 \\
\hline 10 & 0.093447 & 52.48060 & 10.63115 & 7.907942 & 2.821946 & 1.070187 & 25.08818 \\
\hline
\end{tabular}

For the 4-quarters ahead forecast error variance, reported in column 2 of Table 6, the real M3 money demand itself explains about 74 percent of its variation, while all its determinants explain only the remaining 26 percent. Of this 26 percent, the national income explains about 6 percent, exchange rate about 9 percent, CPI about 2 percent, prime overdraft rate about 3 percent, and foreign interest rate about 4.8 percent. However, after a period of two years, the real M3 money demand explains about 57 percent of its own variation, while its determinants explain the remaining 43 percent. The influence of the national income increases substantially to about 11.2 percent, explaining the second largest component of the 43 percent variation in the real M3 money demand that is explained by its determinants. The foreign interest rate explains the largest component (20.3\%) of the 43 percent variation in the real M3 money demand that is explained by its determinants.

Exchange rate accounts for about 4.9 percent and CPI, about 5.5 percent, with its impact increasing over time while exchange rate, with its impact declining over time. Thus, the national income explains the largest component of the variation in the real M3 money demand followed by the foreign interest rate and exchange rate. Shocks to the other variables continued to explain a less significant proportion of the variation in the real M3 money demand. These results, therefore, are similar to those from the impulse response analysis in that only the national income, the exchange rate, and foreign interest rate have a significant impact on the real M3 money demand in the short run. 


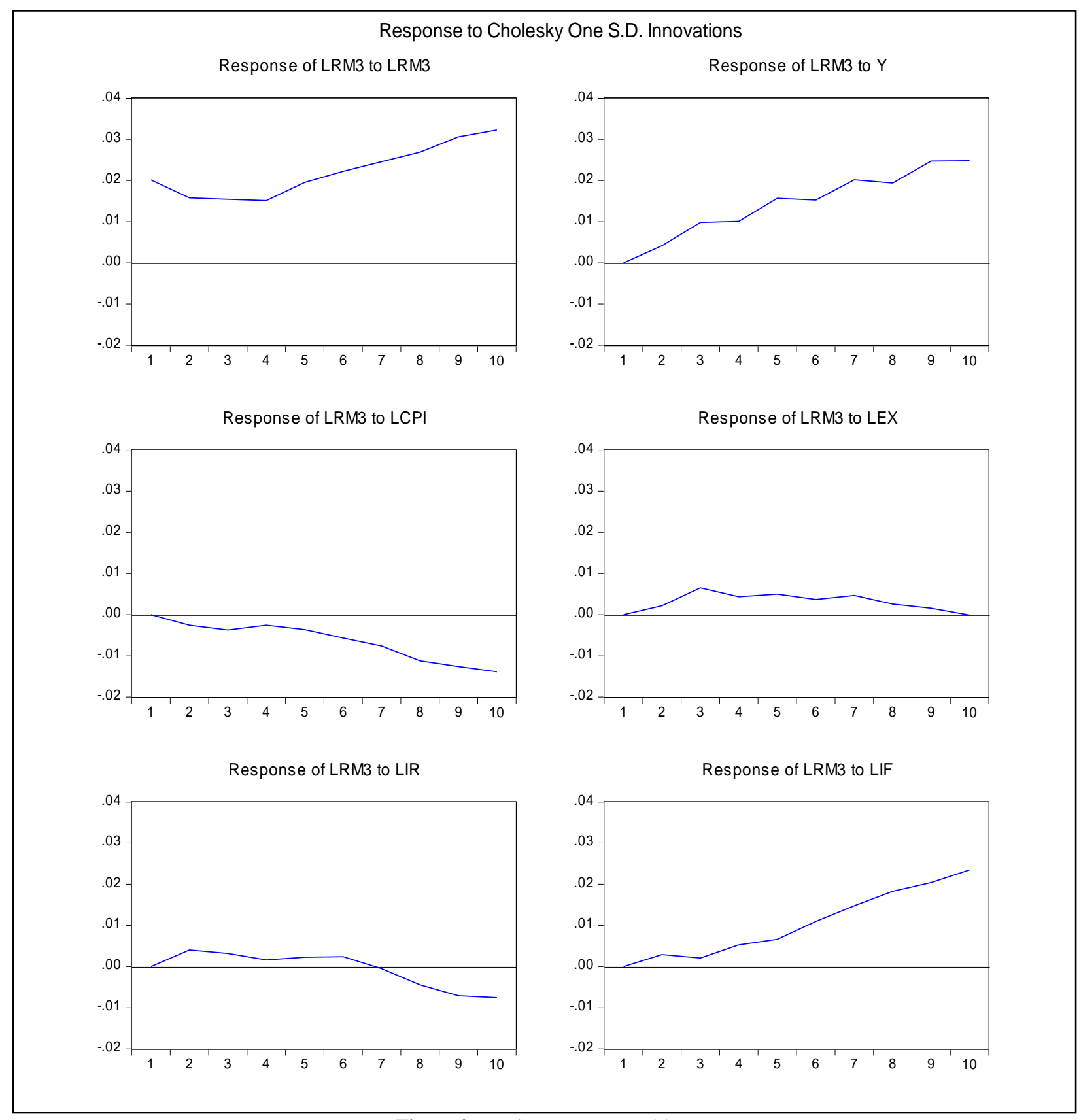

Figure 2: Variance Decomposition

\section{Stability Of Money Demand Tests (CUSUM And CUSUMSQ Test)}

In this section, the central issue for empirical analysis is the stability of the parameters of the real $M 3$ money demand equation (Equation (4)). It is now a standard practice to incorporate short-run dynamics in testing for stability of the long-run parameters of a money demand equation (Owoye and Onafowora, 2007:11). To this end, the approach by Bahmani-Oskooee and Shin (2002) is followed and the cumulative sum of recursive residuals (CUSUM) and cumulative sum of squares of recursive residuals (CUSUMSQ) tests developed by Brown et al. (1975) are applied to the residuals of Equation (4). 
The CUSUM and CUSUMSQ test statistics are updated recursively and plotted against break points in the data (Owoye and Onafowora, 2007:11). For stability of the short-run dynamics and the long-run parameters of the real broad money demand function, it is important that the CUSUM and CUSUMSQ statistics stay within the 5\% critical bound (represented by two straight lines whose equations are detailed in Brown et al., 1975, Section 2.3). As seen in Figure 3, the CUSUMSQ plots do not cross the 5\% critical lines, while the CUSUM plots for M3, cross the upper 5\% boundary slightly in 1998 and from 2006 to 2008. Caporale and Pittis (2004) show that The CUSUM-ofsquares test is to be preferred, as it is very powerful to detect changes in the conditional model parameters, whether or not the variance of the regression error is included in the set of parameters shifting, especially towards the end of the sample. Therefore, it can be concluded that the estimated parameters for the short-run and long-run dynamics and long-run of the real $M 3$ money demand function are stable and that there is evidence of instability of real M3 money demand in some periods, which may be attributed to external shocks, such as the Asian financial crisis in 1998 and the global financial crisis in 2008. In other words, a stable real M3 demand function exists over the entire sample period. These empirical results support the SARB in its choice of real $M 3$ as an intermediate target for monetary policy formulation.

\section{SUMMARY AND CONCLUSION}

The goal of this paper has been to examine the impacts of the various determinants of real broad money demand on the South African money demand and to assess the stability of its function. By means of a sample of quarterly data from January 1990 to December 2009, analyzed by descriptive and econometric techniques, evidence from this study shows that the series of broad money in South Africa, and its hypothesized determinants, are generally I(1) series. Results show that all the hypothesized determinants of money demand have an impact on real broad money demand in South Africa. CUSUM and CUSUMSQ tests confirmed the stability of South Africa's money demand function, which is shown in Figure 3.

Taken together, the results of this study have a number of policy implications. First, the presence of longrun co-movements (co-integration) between the real money demand and its determinants found in this study implies the effectiveness of targeting one of the variables in influencing the long-run behaviour of the other variables. If this interpretation holds, and given the significant long-run relationship between the real money demand and the monetary policy variables in this study, it would justify the stance taken by the monetary authorities in South Africa of pursuing a sound monetary policy by targeting the rate of inflation. There is some concern, however, on the nonnormality of the data. Robust estimates are clearly an item for future research. The impulse response analysis shows that real money demand responds to the interest rate after six quarters. A stable money demand function is a key factor in macroeconomics analysis, especially in selecting appropriate monetary policy (Ziramba, 2007). Stability of the money demand function in this study means that monetary policy is effective in South Africa and the SARB can consider targeting the variables in the money demand model specified in this study. Specifically, if a stable relationship exists between the demand for money and its determinants, changes in the money supply can provide useful information about inflation in the medium and longer terms (Hall et al., 2008:85). Finally, the results show that foreign interest rates do affect the demand for money in South Africa, so monetary policy authorities should consider changes in foreign interest rates. Thus, the demand for money in South Africa depends, in part, on capital mobility measured here by movements in foreign interest rates and expected exchange rates (either jointly or separately). 


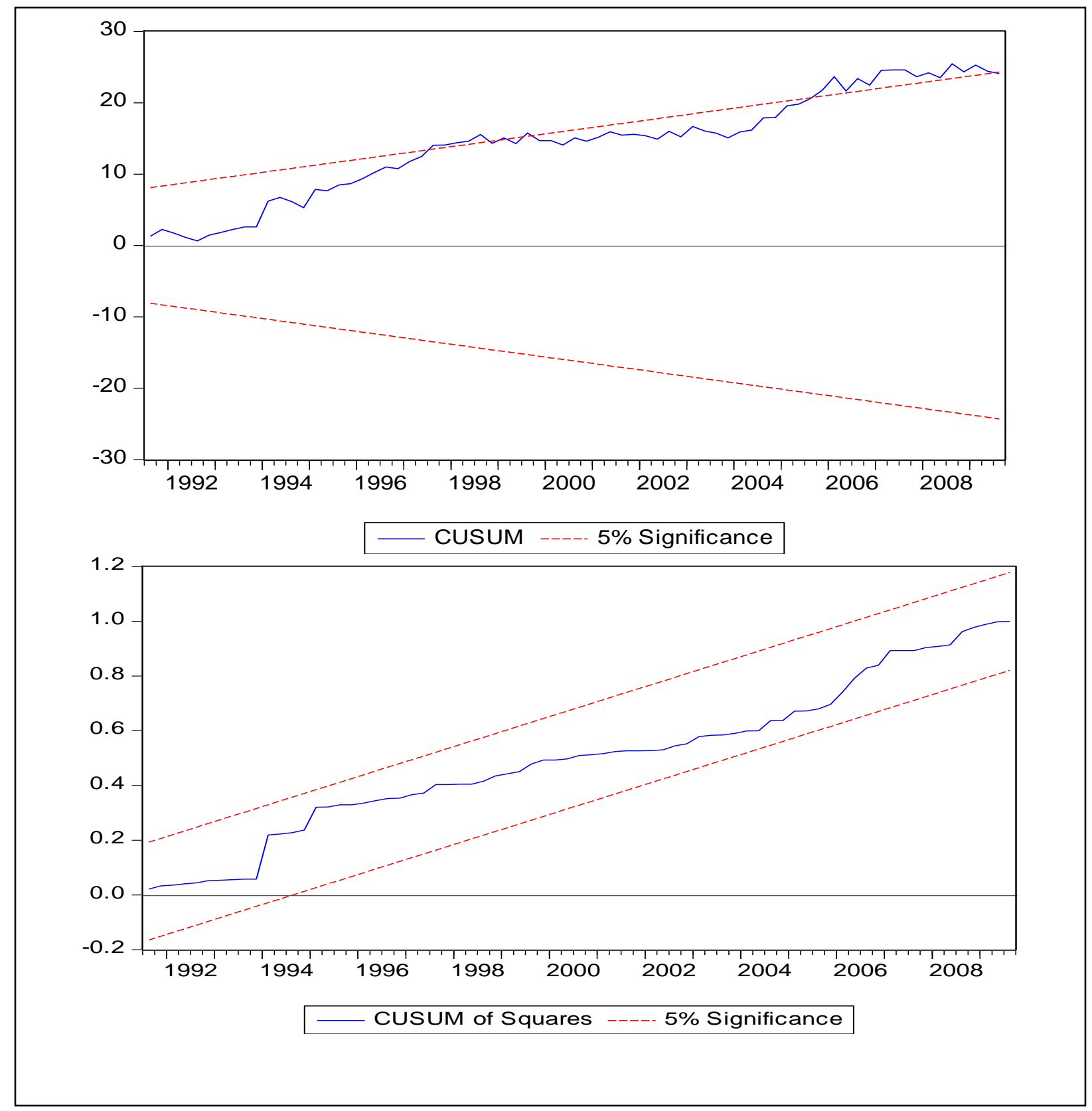

Figure 3: CUSUM And CUSUMSQ Tests Results

\section{AUTHOR INFORMATION}

Moreblessing Simawu is a Masters student at the University of Fort Hare's School of Business Management and Economics, South Africa. Email: $\underline{\text { msimawu@ gmail.com }}$

Courage Mlambo is a $\mathrm{PhD}$ (Economics) candidate at the University of Fort Hare's School of Business Management and Economics, South Africa. E-mail: mlamboct@gmail.com (Corresponding author)

Genius Murwirapachena is a $\mathrm{PhD}$ (Economics) candidate at the Nelson Mandela Metropolitan University's School of Economics, Development, and Tourism, South Africa. E-mail: murwiragenius@ gmail.com 


\section{REFERENCES}

1. Akinboade, O.A., Niedermeier, E.W. \& Siebrits F.K., (2001), South Africa's Inflation Dynamics: implications for policy. Retrieved from:

2. http://www.essa.org.za/download/papers/07.pdf (August 23, 2010)

3. Al Samara, M., (2010), An Empirical Analysis of the Money Demand Function in Syria. Economic Centre of Sorbonne, University of Paris-1 Panthéon-Sorbonne. Retrieved from:

http://www.univ-orleans.fr/leo/infer/ALSAMARA.pdf (May 10, 2011)

4. $\quad$ Asteriou, D., \& Hall, S.G. (2007). Applied Econometrics: a modern Aproach. (Revised ed.). New York.: Palgrave Macmillan.

5. Baharumshah, A.Z., Mohd, S.H., \& Yol, M.A. (2009). Stock prices and demand for money in China: New evidence. Int. Fin. Markets, Inst. and Money 19 (2009) 171-187.

6. Bahmani-Oskooee, M. (2001).How stable is M2 money demand function in Japan? Japan and the World Economy, Volume 13, Issue 4, December 2001, Pages 455-461.

7. Bahmani-Oskooee, M. \& Gelan, A., (2008), How stable is the demand for money in African countries? Retrieved from: http://www.emeraldinsight.com/Insight/viewPDF. (April 14, 2010)

8. Bahmani-Oskooee, M., \& Ng, R. C. W., (2002). "Long-Run Demand for Money in Hong Kong: An Application of the ARDL Model", International Journal of Business and Economics, 1, pp. 147-155.

9. Bahmani-Oskooee, M., \& Shin, S., (2002). Stability of the Demand for Money in Korea: International Economic Journal, 2002, 16:2, 85-95.

10. Bischoff, C. W., \& Belay, H. (2001). The Problem of Identification of the Money Demand Function. Journal of Money, Credit and Banking, Vol. 33. No. 2 pp. 205-215. Retrieved from: http://www.jstor.org/stable/2673881(August 23,2010).

11. Bjørnland H.C. (2004).A stable demand for money despite financial crisis: The case of Venezuela. [Online] Available: http://home.bi.no/a0310125/APE_MD.pdf (June 02,2011).

12. Brooks, C. (2008). Introductory econometrics for finance. New York.: Cambridge University Press.

13. Brooks, C. (2002). Introductory econometrics for finance. Cambridge: Cambridge University Press.

14. Brown, R. L., Durbin J., \& Evans, J.M. (1975). Techniques for Testing the Constancy of Regression Relations Over Time. Journal of the Royal Statistical Society, 1975, 37, 149-192.

15. Caporale, G.M., \& Pittis, N. (2004). Robustness of the CUSUM and CUSUM-of-Squares Tests to Serial Correlation, Endogeneity and Lack of Structural Invariance:Some Monte Carlo Evidence. Institute for Advanced Studies, Vienna.

16. Clarida, R. \& Gertler, M. (1997). How the Bundesbank Conducts Monetary Policy. European Economic Review. Volume. 42(6), pages 1033-1067.

17. Courakis, A. S. (1984). The demand for money in South Africa: Towards a more accurate perspective. South African Journal of Economics, 52(1): 1-39.

18. Diu, N.H., \& Pfau, D.W. (2010), The Determinants and Stability of Real Money Demand in Vietnam, 1999-2009.National Graduate Institute for Policy Studies (GRIPS), Tokyo, Japan. Retrieved from http://www3.grips.ac.jp/ pinc/data/10-14.pdf (February 28, 2011).

19. Dreger, C \& Wolters, J., (2010). Investigating M3 money demand in the euro area, Original Research Article. Journal of International Money and Finance, Volume 29, Issue 1, February 2010, Pages 111-122. Eviews (2007). Eviews 6 Users Guide. Quantitative Micro Software (QMS) Inc, USA.

20. Eviews 7 user's guide (2009). Quantitative Micro Software, LLC, USA.

21. Fielding, D. (1994). Money Demand in Four African Countries. Journal of Economic Studies Vol. 21 No. 1, 1994, pp. 17-51. MCB University Press, UK.

22. Gidlow, R.M. (1998). Student guide to the South African financial system. International Thomson publishing. Johannesburg, South Africa.

23. Granger, C.W.J. (1969). Investigating Causal Relations by Econometric Models and Cross-Spectral Methods. Econometrica. 37: 424-438.

24. Granger, C.W.J \& Newbold, P. (1974). Spurious regressions in econometrics. J. Econometrics, 2: 110-120.

25. Granger, C.W.J., \& Newbold, P. (1986). Forecasting Economic Time Series. (2 ${ }^{\text {nd }}$ ed.). Academic Press.

26. Halicioglu, F. \& Ugur, M. (2005). On Stability of Demand Money Demand Function: Evidence from a Developing OECD Country. Global Business and Economic Review, Vol.7, No.3,September 2005, forthcoming. Retrieved from: http://129.3.20.41/eps/mac/papers/0508/0508001.pdf (May31, 2011) 
27. Hall, S. G., Hondroyiannis, G., Swamy, P.A.V.B., \& Tavlas, G. S. (2008). Where Has All the Money Gone? Wealth and the Demand for Money in South Africa. Journal of African Economies, Volume 18, Number 1, p. 84-112.

28. Hamori, S. (2008). Empirical analysis of the Money Demand Function in Sub- Saharan Africa. Economics Bulletin, Vol.15, No.4pp1-15.

29. Hayo, B. (2008). Estimating a European demand for money. Scottish Journal of Political Economy, Vol. 46, No. 3, August 1999 .Published by Blackwell Publishers Ltd, , UK

30. Hoffman, D.L., Rasche, R. H., \& Tieslau, M. A. (1995). The stability of long-run money demand in five industrial countries. Journal of Monetary Economics 35 (1995) 317-339.

31. Hurn, A. S. (1991). Interest rates, inflation and stability of the demand for M3 in South Africa. Greek Economic Review 13(2): 251-268.

32. Hurn, A. S. \& Muscatelli, V. A. (1992). The long-run properties of the demand for M3 in South Africa. South African Journal of Economics, 60(2): 158-172.

33. Hussain, Z., Awan, H., Hussain, I., Farhan, M.,\& Haq, I. (2006). Demand for Money in Pakistan. International Research Journal of Finance and Economics, Issue 5 (2006). EuroJournals Publishing, Inc. 2006. Retrieved from: http://www.eurojournals.com/finance.htm (June 23, 2010).

34. Hsing, Y.(2007). Impacts of Currency Depreciation, The Foreign Interest Rate, and Functional Forms on Croatia's Money Demand Function. International Research Journal of Finance and Economics. EuroJournals Publishing, Inc. Retrieved from:http://www.eurojournals.com/1hsing.pdf (March 17, 2011).

35. Inoue, T., \& Hamori, S., (2008). An Empirical Analysis of the Money Demand Function in India Retrieved from: http://www.ide.go.jp/English/Publish/Download/Dp/pdf/166.pdf (August 23, 2010)

36. Johansen, S. \& Juselius, K., (1990). Maximum Likelihood Estimation and Inference on Co-integration: with Application to the Demand for Money. Oxford Bulletin of Economics and Statistics, Vol. 52, pp. 169210 .

37. Johansen, S., (1992). Determination of Co-integration Rank in the Presence of a Linear Trend. Oxford Bull. Econ. Stat., 54: 383-397.

38. Johansen, S. (1995). Likelihood-based Inference in Cointegrated Vector Autoregressive Models. Oxford University Press, UK.

39. Jonsson, G. (2001). Inflation, money demand, and purchasing power parity in South Africa. IMF Staff Papers, 48(2):243-265.

40. Lütkepohl, H. \& Reimers, H. E., (1992). Impulse response analysis of a cointegrated system. Journal of Economic Dynamics and Control. pp16: 53-78.

41. Marquez, J. (1987). Money Demand in Open Economies: A Currency Substitution Model for Venezuela. Journal of International Money and Finance, 6, pp. 167-178.

42. Maxwell, T. (1971). The long run demand for money in South Africa (1918-60): Some preliminary findings. South African Journal of Economics, 39(1): 13-30.

43. Mboweni T.T. (2000). The monetary policy stance. South African Reserve Bank Quarterly Bulletin. Vol No. 216, p. 67.

44. Mellander, E., Vredin, A., \& Warne, A. (1992). Stochastic trends and economic fluctuations in a small open economy. Journal of Applied Econometrics. 7: 369-394.

45. Mishkin, F. S. (2004). The economics of money, banking, and financial markets. ( $7^{\text {th }}$ ed.). New York: Pearson Adisson Wesley publishers.

46. Moll, P.G. (1999). Money, interest rates, income and inflation in South Africa. South African Journal of Economics 67(1): 34-64.

47. Muscatelli A.V. \& Spinelli, F. (2000).The long-run stability of the demand for money: Italy 1861-1996. Journal of Monetary Economics 45 (2000) 717-739. Elsevier Science B.V.

48. Naude, W. A. (1992). Do error correction models contribute towards understanding money demand in South Africa?A note. Journal of Studies in Economics and Econometrics, 16(3): 51-62.

49. Nell, K.S. (1999). The stability of money demand in South Africa, 1965-1997. Retrieved from: http://www.ideas.repec.org/p/ukc/ukcedp/9905.html. (April 14, 2010).

50. Onanuga, A.T. \& Shittu, A.M. (2010). Determinants of interest rates in Nigeria: An error correction model. Journal of Economics and International Finance Vol. 2(12), pp. 261-271, November 2010.

51. Owoye, O. \& Onafowora, O.A. (2007). M2 Targeting, Money Demand, and Real GDP Growth in Nigeria: Do Rules Apply? Journal of Business and Public Affairs, 1(2), 1-20. 
52. Stals, C. (1997). Effect of the changing financial environment on monetary policy in South Africa. Economic Society of South Africa. Pretoria, South Africa.

53. Tahir, J. (1995). Recent Developments in Demand for Money Issues: Survey of Theory and Evidence with Reference to Arab Countries. Economic research forum. Retrieved from: http://idlbnc.idrc.ca/dspace/bitstream/10625/34547/1/126364.pdf (July 07, 2011).

54. Tang, T. C. (2002). Demand for M3 and expenditure components in Malaysia: Assessment from bounds testing approach. Applied Economics Letters, 9: 721-725.

55. Tang, T.C, (2004). Demand for broad money and expenditure components in Japan: an empirical study Japan and the World Economy, Volume 16, Issue 4, December 2004, Pages 487-502.

56. Tang, T.C, (2007).Money demand function for Southeast Asian countries. An empirical view from expenditure components. Journal of Economic Studies Vol. 34 No. 6, 2007 pp. 476-496, Emerald Group Publishing Limited.

57. Tavlas, G. S. (1989). The demand for money in South Africa: A test of the buffer stock model. South African Journal of Economics, 57: 1-13.

58. Todani, K. (2007). Long-run M3 Demand in South Africa:A cointegrated VAR model. South African Journal of Economics , 75 (4), 681 - 692.

59. Urzua, C. M. (1997). Omnibus tests for multivariate normality based on a class of maximum entropy distributions. Advances in Econometrics.12: 341-358.

60. Van Der Merwe, E. J. (1999). Monetary policy Operating Procedures in South Africa. [Online] Available: http://www.bis.org. (June 20, 2010).

61. Wang, Y. (2004), Long-run Stability of Demand for Money in China with Consideration of Bilateral Currency Substitution. Retrieved from

62. https://editorialexpress.com/cgi-bin/conference/download.cgi?db_name=SERC2007\&paper_id=49 (June 02, 2011).

63. Wang, Y. (2011), The stability of long-run money demand in the United States: A new approach. Retrieved from: http://0-www.sciencedirect.com.wam.seals.ac.za/science (April 29, 2011)

64. Wesso G.R. (2002), Broad money demand and financial liberalisation in South Africa.South African Reserve Bank Occasional paper 18. Retrieved from: http://www.resbank.co.za (April 14, 2010).

65. Ziramba, E. (2007), Demand for money and expenditure components in South Africa: Assessment from unrestricted error-correction models. Retrieved from: http://www3.interscience.wiley.com/cgibin/fulltext/117962055/PDFSTART (May 05, 2010). 


\section{NOTES}

